\title{
ETHICAL TRAINING IN THE PROFESSION: THE SPECIAL CHAL- LENGE OF THE JUDICIARY
}

\author{
V. ROBERT PAYANT*
}

I

INTRODUCTION

Ethics for lawyers and ethics for judges have the same ultimate goal: ensuring that the personal and professional activities of lawyers and judges are governed in a manner that achieves justice and the appearance of justice in legal proceedings. However, the rules governing the two professions, the mechanisms for enforcement of these rules, and the methods of training vary substantially.

Judges come to the bench from varied backgrounds. Some have considerable experience as litigators, while others have little or no courtroom experience. Judges are governmental employees, work for society as a whole, and are paid a salary. In states that elect judges, continuation in office depends on successful political campaigns.

Although some lawyers work in the public sector, most are in private practice and depend on client fees for their livelihood. Lawyers are advocates rather than decisionmakers.

Because of these fundamental differences, the institutions that educate people to be lawyers, and in many instances provide for the continuing education of lawyers, are not the institutions that have been created to train judges.

The National Judicial College ("NJC") is an institution with the specific mission to train judges. Because of its unique mission, structure, and participant body, a brief history of NJC may be helpful to a discussion of its role and procedures in teaching ethics to judges. Following this discussion is a companion history of the notion of judicial ethics, which draws the distinction between ethics for lawyers and judges necessary to explain NJC's function.

\section{II}

\section{History OF THE NATIONAL JUdicial COllege}

NJC began as an experiment in 1963 in response to the work of the American Bar Association ("ABA") Commission on the More Effective Administration of Justice. After taking a hard look at the courts in various 
states, including public hearings in a number of cities, United States Supreme Court Justice Tom C. Clark, chair of the Commission, and his colleagues concluded that states, particularly those with an elected judiciary, had judges whose legal acumen and judicial temperament varied widely and that many judges lacked even rudimentary skills necessary to conduct trials. They thought it clear that too many judges did not understand, or were unwilling to follow, the ethical standards appropriate to their role as neutral decisionmakers. With no disciplinary body to investigate and sanction unethical behavior of judges, and without a developing body of opinions regarding ethical judicial conduct, some method of transmitting the best thinking of good judges was needed. Education was thought to be the key.

Acting on the Commission's recommendation that an experimental program for judicial education be devised that would emphasize training in bench skills and judicial ethics, a special ABA committee on judicial education was established with Justice Clark as chair and Ernest C. Friesen as staff director. Various members of the committee made suggestions on which topics they felt most important for new judges. The committee and Mr. Friesen devised a curriculum and recruited faculty for a four-week course directed at state trial judges of general jurisdiction. Funds to begin the program, which was initiated in 1964 in borrowed classrooms in the law school at the University of Colorado at Boulder, were received from the Max C. Fleischmann Foundation.

Some basic principles were adopted in arranging the initial course. Most of the faculty were active judges with substantial experience on the bench. Rather than training in the law, the "art and science of judging" was the objective of the training. The supposition was that the student judges, the "participants," either knew or could find the law but that the transition from lawyer to judge required training. By using an expression like "art and science" in reference to judging, the founders meant the demeanor of judges, their behavior in and out of court, their management of dockets, and their methods of reaching decisions and communicating those decisions. The substantive topics taught in law schools such as torts, contracts, and insurance served only as the framework to discuss how various matters should be handled.

Course designers utilized relatively advanced understanding of adult educational methods. Class periods were interactive and were followed by small group discussions led by experienced judges who had received special training as discussion leaders. These discussion leaders met regularly with faculty members and structured the discussion sessions to cover the matters presented in the classrooms. Avoiding "war stories," the discussions drew on the collective knowledge of the participants.

Despite a concern that elected judges might be reluctant to allow their constituents to know that they needed further training, the initial session was oversubscribed, and the eighty-four judges attending represented every state. At the conclusion of the four weeks, the participants enthusiastically urged a continuation of the experiment. 
A permanent home and additional funding was needed and Boulder, along with several other locations, was considered. One of the judges attending the first session was from Reno, Nevada. Upon his return home, he approached the trustees of the Max C. Fleischmann Foundation and determined they would be receptive to hearing from Justice Clark about this "school for judges." The trustees of the Foundation, which was created by the will of Major Max Fleischmann, had made a number of gifts to the University of Nevada and other institutions in Northern Nevada. Restricted only by Major Fleischmann's admonition to "do good things and if possible do them in Northern Nevada," the Foundation's trustees found a judges' school established to serve the entire nation to be a particularly attractive idea.

The Foundation granted the funding for the 1965 session on the condition that it be held in Reno. Using classrooms borrowed from the University of Nevada and housing the judges at an abandoned Air Force base north of Reno, the session was an academic success and convinced the Fleischmann trustees to continue and expand financial support. A permanent staff was hired led by Lawrence M. Hyde, who had been serving as a family court judge in St. Louis, Missouri.

Over the next few years, additional courses beyond the four-week session were added. In 1971, the Fleischmann Foundation granted funds to build the Judicial College Building on the University of Nevada, Reno campus and provided a law library. In 1978, the Foundation purchased a private dormitory near the campus and gave it to the university, stipulating that priority use must be given to the judges attending NJC courses.

Operated as a committee of the ABA from its beginning, NJC was incorporated in 1978 as a non-profit Nevada corporation with its board of directors (now a fifteen-member board of trustees) selected by the ABA Board of Governors, which also acts as the "corporate member" of the College.

NJC now presents more than fifty resident courses each year, varying in length from two-and-one-half days to three weeks. More than 3,000 judges attend NJC resident courses, extension programs, and workshops each year. Every state is represented, and a substantial number of judges from other nations attend NJC courses. Funding comes from tuition, gifts and grants from individuals, foundations, and corporations and income from a modest endowment.

While courses in judicial ethics have been a part of NJC's curriculum since its first session, in recent years, NJC has integrated ethics into a broad spectrum of courses so that virtually every course has an "ethics" component.

\section{III}

\section{JUDICIAL ETHICS, YESTERDAY AND TODAY}

The formal treatment of rules of judicial ethics as separate from the canons governing the professional conduct of lawyers had its origin in 1922, when a committee to study judicial ethics was appointed by the ABA. Chaired by Chief 
Justice William Howard Taft, the committee's recommendations were presented at the forty-seventh annual meeting of the ABA in Philadelphia in 1924.

Styled the "Canons of Judicial Ethics," thirty-six separate canons were proposed and adopted. The Canons were prefaced by quotations from Deuteronomy, the Magna Carta, and Bacon's essay Of Judicature, and expressed both general principles of good conduct and some very specific rules." For example, Canon 5, "Essential Conduct," tells a judge that "he should be temperate, attentive, patient, impartial and since he is to administer the law and apply it to the facts, he should be studious of the principles of the law and diligent in endeavoring to ascertain the facts." 2 These 1924 Canons have been characterized as "a curious mixture of generalized, hortatory admonitions and specific rules of standards for proscribed conduct."3

Besides admonishments to "exhibit an industry and application commensurate with the duties imposed upon him,"4 the 1924 Canons use a word currently in vogue to regulate a judge's temperament. Headed "Courtesy and Civility," Canon 10 dictates that a judge "should be courteous to counsel, especially to those who are young and inexperienced, and also to all others appearing . . . in the court."

These were the ethical standards in effect when NJC began. With few enforcement mechanisms in place other than impeachment proceedings, the NJC ethics classes used, for many years, the canons and the advisory opinions issued by the ABA Committee on Professional Ethics and Grievances on both the Judicial Canons and the Canons of Profession Ethics governing lawyers. The 1924 Canons were superseded in 1972 with the ABA's adoption of the Model Code of Judicial Conduct. Composed of seven canons, this new effort contained most of the topics covered in the earlier version and continued to blend general standards and specific rules. However, most of the new standards were to be mandatory and enforceable. Combined with the state-by-state adoption of judicial discipline bodies that could impose or recommend sanctions against errant judges, the training of judges became more than an academic exercise.

By 1981, all fifty states and the District of Columbia had established judicial discipline bodies that could investigate, prosecute, and, to some degree, impose sanctions. Judges found to have violated the ethical standards faced penalties ranging from verbal (sometimes private) admonishment to removal from office.

Following the quick adoption by a number of states of the 1972 Code, NJC in 1973 published its first textbook on judicial ethics. Designed to be used as a text for courses and also as a reference book in chambers, the text was revised

1. Canons of Judicial Ethics Ancient Precedents (1924).

2. Id. Canon 5.

3. John F. Sutton, Jr., A Comparison of the Code of Professional Responsibility with the Code of Judicial Conduct, 1972 UTAH L. REV., 355, 355-56.

4. CANONS OF JUdicial ETHICS Canon 6 (1924).

5. Id. Canon 10. 
for a second edition in 1975 , followed by a third edition in 1982 . Several reprints were made thereafter with little change in the text.

In 1986, a survey conducted by the ABA Standing Committee on Ethics and Professional responsibility found that the 1972 Code needed a comprehensive review. With grants from the Josephson Institute for the Advancement of Ethics and from the State Justice Institute, the Standing Committee, with substantial input from the judiciary, the bar, and the general public, prepared the Model Code of Judicial Conduct. ${ }^{6}$

Reduced to five canons, the new Model Code adds some significant sections regarding ex parte matters ${ }^{7}$ and clarifies, in the commentary, some matters involving political activities of judges. ${ }^{8}$ The 1990 Code imposes mandatory standards by use of the word "shall" in the text of the canons and "must" in the commentary while those matters that are aspirational rather than mandatory use "should" and "may" in the text and commentary respectively.

More than twenty states have now adopted the 1990 Code, some with rather substantial changes from the original. NJC published its Modern Judicial Ethics, based on the 1990 Code in 1992 and is using the 1995 edition in its courses for judges.

\section{IV}

\section{ETHICS FOR LAWYERS, ETHICS FOR JUDGES}

Today, as when NJC was begun, judges come to the bench with widely varying experiences and training. Nearly 10,000 of the approximately 30,000 state judges take on their judicial responsibilities with no training in the law whatsoever, let alone in the ethical standards that govern judges. While these judges and magistrates are in courts of special or limited jurisdiction, many of them determine significant legal matters, some conducting trials by jury. In traffic and misdemeanor courts, these judges are the image of justice observed by far more people than those appearing in felony and appellate courts. Even the judges who are trained in the law and who have appeared in courts many times generally have little real knowledge about the code of judicial conduct until they actually become judges.

Judges quickly discover that they face ethical issues that impact various aspects of their professional and personal lives:

(1) their behavior on and off the bench;

(2) the behavior of their families;

(3) their responsibilities regarding the conduct of the court staff and the lawyers who appear in their courts; and, ultimately,

6. Model Code of Judicial Conduct (1990).

7. Id. Canon $3 \mathrm{~B}(7)$.

8. Id. Canon $5 \mathrm{cmt}$. 
(4) the impact of their behavior (or perceived behavior) on the very essence of the justice system - the integrity of judges and their independence in decisionmaking.

$\mathrm{V}$

Ethics Training at the National Judicial College

Ethics training at NJC proceeds along four separate tracks.

\section{A. General Courses}

The general courses at NJC are designed for new judges in general jurisdiction courts (three weeks) and in special courts (two weeks), new nonlaw-trained judges in special courts (two weeks), and new administrative law judges in both state and federal agencies (two weeks). In recent years, NJC has also offered a two-week course for new judges of appellate courts, which has been especially valuable for appellate judges without trial court experience.

Ethics classes follow the general NJC formula, using a variety of adult education techniques, including some lectures, role-playing, stop-action video vignettes, and hypothetical cases. These cases are usually based on actual adjudicated cases decided by the courts or judicial discipline bodies. The illustrations cover a broad range of issues including judicial bias and abusive bench behavior. For example, in a simple role-playing exercise, a male judge may be asked to interview a prospective court employee, played by a female judge. Questions dealing with personal issues, comments as to the attractive appearance of the applicant, raunchy humor, and suggestions on reciprocal favors can open an entire hour discussion on harassment, use of judicial office for personal gain, and bringing disrepute to the courts. Scenarios involving ex parte communications with lawyers, solicitations of campaign funds, and campaign tactics in judicial elections are among the ways the ethics classes can be made lively, memorable, and real.

The racial and gender task forces, which have now been conducted in a majority of states, are replete with shocking evidence of bias on the part of judges. While the percentage of judges who exhibit such behavior appears small, the devastating effect on the perception of the courts is immense, especially among women and minorities.

In addition to the high ethical standards required of judges in their private and public lives, they have been charged with responsibilities concerning the behavior of others in the justice system. These issues are part of the "role of the judge" portion of the general courses, which deals with the responsibilities of judges as adjudicators, administrators, change-makers (politicians), and moral symbols. These classes and group discussions look especially at the administrative and disciplinary responsibilities of judges. Canon $3 \mathrm{C}(1)$ establishes the rule that court officials adhere to "the same standards of fidelity and diligence" that apply to the judge, and the class discussions center on how judges are to ensure that staff members perform according to that standard. 
These classes also focus on several canons addressing a judge's role. Canon $3 \mathrm{C}$ requires judges to administer the courts without bias or prejudice and requires staff and court officials subject to the judges' direction to observe the same standards of fidelity, diligence, and impartiality required of the judge. Canon $3 \mathrm{~B}(6)$ establishes the duty of judges to require lawyers to refrain from manifesting bias or prejudice, ${ }^{9}$ and Canon $3 \mathrm{D}$ requires a judge to report lawyers' violations of the Rules of Professional Conduct to appropriate discipline bodies. ${ }^{10}$ This same Canon places a duty on judges that is even more onerous but more important-the duty of taking action against another judge if there is significant information that the other judge has violated the Code. ${ }^{11}$

While the state court systems vary regarding the methods of selecting court employees and the authority of judges regarding court employment matters, the public perception of the courts is formed as much by the behavior and attitudes of court employees and lawyers as by the behavior of the judge. Despite variances in the systems, the group discussions at NJC dealing with the judicial responsibilities are designed so judges focus on the wide breadth of their duties that go beyond the adjudication function.

NJC is currently developing a special course dealing with the management responsibilities of presiding judges. While dealing primarily with responsibilities in resource management, computerization of courts, and personnel matters, the course will also deal with the issue of discipline of judges and the responsibility of presiding or chief judges concerning the behavior of their associates on the bench.

\section{B. Special Courses in Ethics}

Since 1992, NJC has annually conducted an in-depth course entitled "Ethics for Judges." This two-and-one-half day course is designed as a study of the ethics codes, but, more significantly, it helps judges take a leadership position in improving the ethical level of their home states' court systems.

State court administrators and chief justices often request judges to attend NJC's special ethics course with the expectation that the judges on their return will become instructors in state judicial education programs.

Touching upon both personal and professional ethics, the course requires all participants to develop action plans to be implemented in their home courts. Each participant decides on the significant aspects of ethical behavior that his or her plan will address and determines the procedures that will be taken to implement the plan. Six months following the conclusion of the course, NJC contacts the participants to review what successes or failures the judges have had in carrying out their action plans.

9. Id. Canon 3B(6).

10. Id. Canon 3D.

11. Id. 


\section{Ethical Election of Judges}

Because state judges decide 95 percent of our nation's court cases, and because forty states use public elections to select or retain judges, few parts of the Code of Judicial Conduct touch most judges as significantly as the Canon dealing with political activities of judges.

Canon 5 of the 1990 Model Code provides that a judge or judicial candidate shall refrain from inappropriate political activity. ${ }^{12}$ Section $5 \mathrm{~A}$ deals with permitted and prohibited campaign activities, including prohibitions of any pledges or promises of conduct in office other than the faithful and impartial performance of duties. ${ }^{13}$ Given this rule, observers of judicial elections are appalled to see candidates, including incumbent judges, promise such things as "cleaning our streets of hoodlums."

Probably the most contentious discussions during the drafting of the 1990 Model Code involved the judicial election issues. In what some commentators ${ }^{14}$ have considered a lowering of the standards relative to participation in partisan political activity, section $5 \mathrm{C}$ permits a judge or candidate, who is subject to public election, to purchase tickets for and attend political gatherings and identify himself or herself as a member of a political party. ${ }^{15}$

Perhaps the area most fraught with danger for judicial candidates, and for the public perception of the justice system, relates to campaign contributions. Canon 5C(2) forbids a candidate to solicit or accept campaign contributions personally, but does permit the candidate to establish committees to conduct a campaign and to solicit funds. ${ }^{16}$

Since there seems little likelihood that the method of judicial selection will change in the near term, NJC has developed a special course entitled "Ethical Issues in the Election of Judges" to keep judges from violating the Code and hopefully raise the tenor of judicial election campaigns from the level to which many have sunk.

In NJC's home state, Nevada, the past two elections for seats on the highest court have seen candidates (incumbent judges) accusing their opponents of accepting under-the-table money, forgetting about cases resulting in parolees committing further murders, and stealing from the estate of an elderly friend. A 1984 Louisiana election for justice of the state supreme court included newspaper advertisements with an accusation against the incumbent justice: "John Dixon Doesn't Think 20 Stab Wounds are Enough," citing the justice's dissent in a death penalty case. ${ }^{17}$ In 1988 , advertisements placed by his

12. Id. Canon 5.

13. Id. Canon $5 \mathrm{~A}$.

14. See Jeffrey Shaman et al., The 1990 Code of Judicial Conduct, 74 JUDICATURE 21 (1990).

15. MODEl CODE OF JUdicial ConduCt Canon 5C (1990).

16. Id. Canon $5 \mathrm{C}(2)$.

17. Patrick M. MCFadden, Electing Justice: The Law and Ethics of Judicial Election CAMPaigns (1990). 
opponent for election to the Texas Court of Criminal Appeals attack an incumbent judge by stating, "The incumbent, Chuck Miller, says we should expand the rights of criminals. Judge Tom Rickhoff says we should not."18

NJC's "Ethical Issues in the Election of Judges" project has been designed to assist judges who serve as NJC faculty members as well as aid state judicial educators who have the responsibility for arranging in-state training for judges and court personnel. The course provides curriculum and course material for conducting a course on judicial elections.

With an expert planning committee including judges, a state judicial educator, and a scholar associated with the American Judicature Society, the election course curriculum was developed and tested at NJC with thirty trial and appellate judges selected by chief justices of the various states.

Now that the topic of judicial elections is incorporated into NJC's regular "Ethics for Judges" course, a special instructional guide for judges and judicial educators has been prepared and sent to each state to assist in the replication of the course. The guide covers solicitation, spending, and management of campaign funds, campaign advertising and political/campaign activity. It helps participants develop action plans to promote ethical campaigns in their home states.

\section{Faculty Training}

One of the significant changes in NJC's method of training its faculty members was the result of a 1992 project developed under a grant from the W.M. Keck Foundation. With the Keck Foundation grant structured to improving ethics in the justice system, a new dimension was added at NJC which has become the method used in all faculty development workshops: focusing the workshop on a single issue and having the faculty, whatever their area of teaching expertise, integrate the focus issue into their teaching. For a number of years, NJC had invited members of its faculty, particularly the volunteer judge faculty, to participate in three-day training workshops during which the philosophy and practice of adult education for professionals was demonstrated. Led by experienced trainers, the participants learned the value as well as the methodology of using audio/visual aids, role-playing, Socratic dialogue, and other adult teaching techniques. As part of the workshop, each participant prepared a micro-presentation of his or her area of expertise. Using a single topic like judicial ethics, which has relevance in every topic taught at NJC, the faculty training workshops attained a more coherent structure by giving innovative ideas on how the overarching topic could be integrated into course presentations.

Judicial ethics was a natural to begin the process and was the focus of the 1992 session. The faculty members discovered that ethical considerations were important and relevant in all of the topics that were part of the NJC curriculum.

18. Sara Mathias, Electing Justice: A Handbook of Judicial Election Reform (1990). 
Whether the faculty member was teaching evidence, sentencing, computer uses, contempt, complex civil litigation, or a dozen other topics, ethical considerations had a place. While not replacing the special classes in the general courses dedicated to a study of the ethics code and its implications, faculty members learned ways of teaching their regular topics with a consideration of the ethics of judicial practices in dealing with the substantive law issues.

Faculty training workshops have now been structured to include both teaching techniques and issues related to ethics, particularly issues of race and gender bias, with the result that ethics training permeates the courses.

VI

\section{CONCLUSION}

While NJC continues to refine and improve its curriculum and teaching methods, training in ethics will continue to be a significant part of its curriculum. With a faculty of more than 250 persons spread across the nation, continued training of faculty to include consideration of ethics issues in substantive legal courses is crucial. Costs of conducting such sessions have deferred the training opportunities for some of the new faculty members who have been invited to teach but resources are being sought to increase the training.

Acquiring more teaching tools for use at NJC and by the state judicial education programs served by NJC is planned. The Ethical Election of Judges manual and the video and training manual on judicial discipline procedure will add to NJC's programs.

The remaining issue deals with methods of guaranteeing that training in ethics is part of the continuing education of judges and that all judges participate. Despite the expansion of mandatory continuing legal education ("CLE") in most states, often including a required ethics component, many states exempt judges from any requirements of continuing education and rarely place any requirements as to specific topics. As a result, human nature being what it is, some judges most in need of training in ethics are unlikely to appear at NJC or at their own state programs. We hope the leaders of the state courts will take steps to find the resources that will support quality education for their judges and then require regular attendance on a career-long basis so that judicial skills and judicial ethics will be strengthened.

A need exists to construct a common ethical framework from which judges can operate. That one has served as an attorney is a foundation, but not sufficient by itself. Experience in advocacy does not necessarily translate into an ability to adjudicate. Additionally, many judges have not come from the practicing bar, and so do not even have the benefit of courtroom observation and interaction. These groups should be given a basic understanding of the roles of a judge and their ethical considerations, both inside and outside the courtroom. NJC provides a continuing forum for fledgling and experienced judges alike to explore and learn how to execute their critical position ethically. 